\title{
A Review on Cr(VI) Adsorption Using Inorganic Materials
}

\author{
Claudia Rosales-Landeros ${ }^{1}$, Carlos Eduardo Barrera-Díaz ${ }^{1 *}$, Bryan Bilyeu ${ }^{2}$, \\ Víctor Varela Guerrero ${ }^{1}$, Fernando Ureña Núñez ${ }^{3}$ \\ ${ }^{1}$ Unidad El Rosedal, Centro Conjunto de Investigación en Química Sustentable, UAEM-UNAM, Toluca, México \\ ${ }^{2}$ Department of Chemistry, Xavier University of Louisiana, New Orleans, USA \\ ${ }^{3}$ Instituto Nacional de Investigaciones Nucleares, Ocoyoacac, México \\ Email: "cbd0044@yahoo.com
}

Received April 30, 2013; revised May 30, 2013; accepted June 17, 2013

Copyright (C) 2013 Claudia Rosales-Landeros et al. This is an open access article distributed under the Creative Commons Attribution License, which permits unrestricted use, distribution, and reproduction in any medium, provided the original work is properly cited.

\begin{abstract}
Chromium compounds are widely used in electroplating, metal finishing, magnetic tapes, pigments, leather tanning, wood protection and electronic and electrical equipment. Hexavalent chromium is a highly toxic metal and produces health damages. The most soluble, mobile and toxic forms of hexavalent chromium in soils are chromate and dichromate and the chromium distribution is also controlled by redox processes, its adsorption decreases with increasing $\mathrm{pH}$ and when competing dissolved anions are present. Several techniques have been developed to remove $\mathrm{Cr}(\mathrm{VI})$ from wastewater but these techniques have disadvantages such as high cost, non-selective, $\mathrm{pH}$ dependence, etc. The use of low cost sorbents has been investigated as a replacement for current costly methods; natural materials with a high adsorption capacity for heavy metals can be obtained. Modification of the sorbents can improve adsorption capacity. This paper includes some techniques for remove $\mathrm{Cr}(\mathrm{VI})$ with clays, silica and zeolites from aqueous solutions, some of the treated adsorbents show good adsorption capacities.
\end{abstract}

Keywords: Sorption; Hexavalent Chromium; Clay; Silica; Zeolites

\section{Introduction}

Hexavalent chromium is a strong oxidizing agent that is water-soluble in its anionic form. Due to its solubility, it is highly mobile in soil and aquatic environments and readily penetrates plant and animal epidermis where it irritates the tissues $[1,2]$. To meet strict environmental regulations, $\mathrm{Cr}(\mathrm{VI})$ in wastewater is typically removed by either adsorption or a reduction + precipitation method, both of which have problems. Adsorption of $\mathrm{Cr}(\mathrm{VI})$ anions by cellulose-based sorbents is relatively ineffective, while carbon is expensive. Therefore, $\mathrm{Cr}(\mathrm{VI})$ anions must be first reduced to $\mathrm{Cr}(\mathrm{III})$ cations for effective sorption. Likewise, to precipitate $\mathrm{Cr}(\mathrm{VI})$, it must first be reduced to $\mathrm{Cr}(\mathrm{III})$. The reduction of $\mathrm{Cr}(\mathrm{VI})$ is advantageous in itself because the trivalent form is a thousand times less toxic [3] and can be effectively adsorbed or precipitated.

The reduction of $\mathrm{Cr}(\mathrm{VI})$ in wastewater is typically done with a reducing agent like iron or iron(II) ions under acidic conditions. The process usually involves lowering the $\mathrm{pH}$ to 1 or 2 , adding reducing agent, then raising the $\mathrm{pH}$ to the level for adsorption or precipitation [4].

${ }^{*}$ Corresponding author.
All of these steps require large amounts of reagents, which affect the cost, the sustainability, the overall quality and ionic properties, and the amount of sludge generated. Thus, new ways to remove $\mathrm{Cr}(\mathrm{VI})$ from wastewater in a single step would be advantageous.

In this review, we focus attention on new ways to remove $\mathrm{Cr}(\mathrm{VI})$ from aqueous solutions using inorganic materials. In this sense we center our study on the use of natural and modified clays, silica and zeolites.

Figure 1 shows a classification of thenatural inorganic materials that have been recently studied for $\mathrm{Cr}(\mathrm{VI})$ sorption.

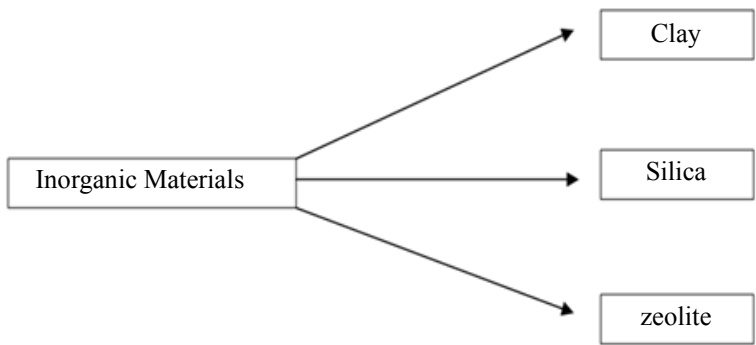

Figure 1. Inorganic materials currently used as $\operatorname{Cr}(\mathrm{VI})$ sorbent materials. 


\section{Clay}

Clay is mineral composed of alumina and silica that usually includes bound water. A mineral is a naturally occurring crystalline material that has a specific or limited range of chemical compositions. Clays have a sheet-like structure and are composed mainly of tetrahedrally arranged silicates and octahedrally arranged aluminates. Kaolinite is the principal mineral in kaolin clays. It is a 1:1 clay mineral with the basic unit being a 2-dimensional (2D) layer of silicate groups tightly bonded to a 2D layer of aluminate groups [5].

Clay occurs in all types of sediments and sedimentary rocks and is a common constituent of hydrothermal deposits. It is the most abundant mineral in sedimentary rocks perhaps comprising as much as $40 \%$ of these rocks. Half or more of the clay minerals in the earth's crust are illites, followed, in order of relative abundance, by montmorillonite and mixed-layer illite-montmorillonite, chlorite and mixed-layer chlorite-montmorillote, kaolinite and septachlorite, attapulgite, and sepiolite. The clay minerals are fine-grained: they are built up of tetrahedrally and octahedrally coordinated cations organized to form either sheets or chains. All are hydrous [6].

Clays exhibit large surface areas and are capable of adsorbing cationic, anionic, and neutral metal species. These materials are also able to participate in cationic and anionic exchange processes. Their sorption capacities, cation and anion exchange properties and binding energies vary widely [8]. Clays are extremely fine particles exhibiting chemical properties of colloids [9]. The high specific surface areas, chemical and mechanical stability, layered structure, high cation exchange capacity (CEC), have made clays excellent adsorbent materials [10]. The classification of clays is shown in Table 1.

Clays intercalated with metal oxides are of enormous importance because of their high thermal stability, high surface area, and intrinsic catalytic activity. These materials are usually prepared by ion-exchange cations in the interlayer region of swelling clays with bulky alkylammonium ions, polynuclear complex ions bearing inorganic ligands (hydroxyl, chloro, etc.), large metal complex ions bearing organic ligands, etc. The intercalated species are capable of preventing the collapse of the interlayer spaces, propping open the layers as pillars, and forming an interlayer space. On heating, the intercalated inorganic species are converted to metal oxide clusters, generating a stable microporous structure with a high surface area [10].

Clays have the property of adsorbing certain ions and retaining them in an exchangeable state. Exchangeable ions are held on external surfaces of the mineral. The CEC is confined primarily to the surface, in contrast to smectites and illites where a large part of the CEC belongs to interior sites. Therefore, to study purely surface
Table 1. Classification of clays.

\begin{tabular}{|c|c|c|}
\hline Group name & Minerals & Chemical composition \\
\hline \multirow{7}{*}{ Kandites } & Nacrite & $\mathrm{Al}_{2} \mathrm{Si}_{2} \mathrm{O}_{5}(\mathrm{OH})_{4}$ \\
\hline & Dickite & $\mathrm{Al}_{2} \mathrm{Si}_{2} \mathrm{O}_{5}(\mathrm{OH})_{4}$ \\
\hline & Kaolinite-Tc & $\mathrm{Al}_{2} \mathrm{Si}_{2} \mathrm{O}_{5}(\mathrm{OH})_{4}$ \\
\hline & Kaolinite-M & $\mathrm{Al}_{2} \mathrm{Si}_{2} \mathrm{O}_{5}(\mathrm{OH})_{4}$ \\
\hline & Metahaloisite & $\mathrm{Al}_{2} \mathrm{Si}_{2} \mathrm{O}_{5}(\mathrm{OH})_{4}$ \\
\hline & Haloisite & $\mathrm{Al}_{2} \mathrm{Si}_{2} \mathrm{O}_{5}(\mathrm{OH})_{4} \cdot 2 \mathrm{H}_{2} \mathrm{O}$ \\
\hline & Anauxite & $\mathrm{Al}_{2} \mathrm{Si}_{2} \mathrm{O}_{5}(\mathrm{OH})_{4}$ \\
\hline \multirow{5}{*}{ Septeclorites } & Antigorite & $\mathrm{Mg}_{6} \mathrm{Si}_{4} \mathrm{O}_{10}(\mathrm{OH})_{8}$ \\
\hline & Crisolite & $\mathrm{Mg}_{6} \mathrm{Si}_{4} \mathrm{O}_{10}(\mathrm{OH})_{8}$ \\
\hline & Amesite & $(\mathrm{Mg}, \mathrm{Fe})_{4} \mathrm{Al}_{4} \mathrm{Si}_{2} \mathrm{O}_{10}(\mathrm{OH})_{8}$ \\
\hline & Cronstedite & $\mathrm{Fe}_{6}\left(\mathrm{Si}_{2} \mathrm{Fe}_{2}\right) \mathrm{O}_{10}(\mathrm{OH})_{8}$ \\
\hline & Berthierine & $(\mathrm{Fe}, \mathrm{Mg}, \mathrm{Al})_{6}\left(\mathrm{Si}_{3} \mathrm{Al}\right) \mathrm{O}_{10}(\mathrm{OH})_{8}$ \\
\hline \multirow[t]{2}{*}{ Clorites } & Clorites & Variable \\
\hline & Illite & $\left(\mathrm{K}, \mathrm{H}_{3} \mathrm{O}\right) \mathrm{Al}_{2}(\mathrm{Si}, \mathrm{Al})_{4} \mathrm{O}_{10}(\mathrm{OH})_{2}$ \\
\hline \multirow[t]{5}{*}{ Mikas } & Glauconite & $\left(\mathrm{K}, \mathrm{H}_{3} \mathrm{O}\right) \mathrm{Al}_{2}(\mathrm{Al}, \mathrm{Fe})_{2} \mathrm{O}_{10}(\mathrm{OH})_{2}$ \\
\hline & Ledikite & $\left(\mathrm{K}, \mathrm{H}_{3} \mathrm{O}\right) \mathrm{Mg}_{3}(\mathrm{Si}, \mathrm{Al})_{4} \mathrm{O}_{10}(\mathrm{OH})_{2}$ \\
\hline & Montmorilonite & $0.33 \mathrm{M}+\left(\mathrm{Al}_{1.67} \mathrm{Mg}_{0.33}\right) \mathrm{Si}_{4} \mathrm{O}_{10}(\mathrm{OH})_{2}$ \\
\hline & Baidellite & $0.33 \mathrm{M}+\mathrm{Al}_{2}\left(\mathrm{Si}_{3.67} \mathrm{Al}_{0.33}\right) \mathrm{O}_{10}(\mathrm{OH})_{2}$ \\
\hline & Nontronite & $0.33 \mathrm{M}+\mathrm{Fe}_{2}\left(\mathrm{Si}_{3.67} \mathrm{Al}_{0.33}\right) \mathrm{O}_{10}(\mathrm{OH})_{2}$ \\
\hline \multirow[t]{5}{*}{ Esmectites } & Volkonskite & $0.33 \mathrm{M}+(\mathrm{Fe}, \mathrm{Cr}, \mathrm{Al})_{2}(\mathrm{Si}, \mathrm{Al})_{4} \mathrm{O}_{10}(\mathrm{OH})_{2}$ \\
\hline & Saponite & $0.33 \mathrm{M}+\mathrm{Mg}_{3}\left(\mathrm{Si}_{3.67} \mathrm{Al} 0.33\right) \mathrm{O}_{10}(\mathrm{OH})_{2}$ \\
\hline & Sauconite & $0.33 \mathrm{M}+(\mathrm{Mg}, \mathrm{Zn})_{3}\left(\mathrm{Si}_{3.67} \mathrm{Al}_{0.33}\right) \mathrm{O}_{10}(\mathrm{OH})_{2}$ \\
\hline & Hectorite & $0.33 \mathrm{M}+(\mathrm{Mg}, \mathrm{Li})_{3}(\mathrm{Si}, \mathrm{Al})_{4} \mathrm{O}_{10}(\mathrm{OH})_{2}$ \\
\hline & Vermiculite & $0.67 \mathrm{M}+(\mathrm{Mg}, \mathrm{Fe}, \text { etc. })_{2}(\mathrm{Si}, \mathrm{Al})_{4} \mathrm{O}_{10}(\mathrm{OH})_{2}$ \\
\hline Vermiculites & $\begin{array}{l}\text { Vermicilite } \\
\text { dioctahedrical }\end{array}$ & $0.67 \mathrm{M}+(\mathrm{Al}, \mathrm{Fe}, \mathrm{etc} .)_{2}(\mathrm{Si}, \mathrm{Al})_{4} \mathrm{O}_{10}(\mathrm{OH})_{2}$ \\
\hline \multirow{2}{*}{ Hormitas } & Sepiolite & $\mathrm{H}_{6} \mathrm{Mg}_{3} \mathrm{Si}_{12} \mathrm{O}_{30}(\mathrm{OH})_{10} \cdot 6 \mathrm{H}_{2} \mathrm{O}$ \\
\hline & Paligorskite & $\mathrm{H}_{4} \mathrm{Mg}_{5} \mathrm{Si}_{8} \mathrm{O}_{20}(\mathrm{OH})_{6} \cdot 6 \mathrm{H}_{2} \mathrm{O}$ \\
\hline
\end{tabular}

Source: [7].

processes, kaolinite may be an ideal material. Acid treatment of clay minerals is an important control over mineral weathering and genesis [10]. Such treatments can often replace exchangeable cations with $\mathrm{H}^{+}$ions and release $\mathrm{Al}^{3+}$ and other cations out of both tetrahedral and octahedral sites, but leaving the $\mathrm{SiO}_{4}$ groups largely intact [11]. It was reported that acid activation followed by thermal treatment increases the adsorbent capacity to a good extent. Table 2 shows the chemical composition of red clay. 
Table 2. Mineralogical and chemical composition of red clay.

\begin{tabular}{cclc}
\hline \multicolumn{2}{c}{ Mineralogical Composition } & \multicolumn{2}{l}{ Chemical Composition } \\
\hline Illite & $23 \%-37 \%$ & $\mathrm{SiO}_{2}$ & $64.79 \%$ \\
Kaolinite & $6 \%-12 \%$ & $\mathrm{Al}_{2} \mathrm{O}_{3}$ & $16.26 \%$ \\
Chlorite & $3 \%-5 \%$ & $\mathrm{Fe}_{2} \mathrm{O}_{3}$ & $7.22 \%$ \\
Quartz & $30 \%-45 \%$ & $\mathrm{MgO}$ & $2.38 \%$ \\
Hematite & $3 \%-6 \%$ & $\mathrm{~K}_{2} \mathrm{O}$ & $2.68 \%$ \\
& & $\mathrm{CaO}$ & $0.4 \%$ \\
& & $\mathrm{TiO}_{2}$ & $0.91 \%$ \\
& & $\mathrm{MnO}^{2}$ & $0.09 \%$ \\
\hline
\end{tabular}

Source: [12].

\section{Surface Modification of Clay}

Clays modified by cationic surfactants, used in chromate removal from water, include bentonite (smectite), stevensite, kaolinite, illite, palygorskite, and sepiolite. The isotherm HDTMA adsorption on clay shows at least two adsorption sites, differing in the energy of interaction with $\mathrm{HDTMA}^{+}$cations, as well as in capacity. It should be noted that the composition of the clay, containing illite, kaolinite and quartz as main components, is the key feature responsible for the characteristics of this isotherm. The first part of the isotherm probably represents HDTMA adsorption on hydrophilic sites, i.e. illite and kaolinite. The dominant interaction in these places is electrostatic attraction of the positively charged surfacetant cations by the negatively charged network of illite and kaolinite. There is, however, a difference in the structure of these two minerals, i.e. illite is a 2:1 type, whereas kaolinite is a 1:1 type clay. Potassium-exchanged kaolinite and illite interact with surfactant cations in the following manner:

$$
\begin{aligned}
& \text { clay }-\mathrm{K}+\mathrm{HDTMA}^{+} \leftrightarrow \text { clay }-\mathrm{HDTMA}+\mathrm{K}^{+} \\
& \text {clay-HDTMA }+\mathrm{HDTMA}^{+} \leftrightarrow \text { clay- }(\text { HDTMA })_{2}^{+}
\end{aligned}
$$

where the first equation refers to ion exchange and the second one relates to a Van der Waals interaction between the alkyl chains of surfactant cations with the consequent formation of a so-called bilayer. Contrary to kaolinite, where the adsorption of surfactant takes place on the mineral surface, in the case of illite, there is also penetration into the interlamellar space and reactions (1) and (2) are more advanced, i.e. surfactant cations are more strongly held by the clay matrix.

The second part of the isotherm is probably a result of Van der Waals and electrostatic interactions between surfactant and the quartz surface. The HDTMA adsorption on non-charged and charged sites on quartz surfaces, resulting from silanols Si-OH dissociation. HDTMAbromide and $\mathrm{HDTMA}^{+}$cations are more easily adsorbed on the hydrophobic surface of quartz than on the hydrophilic surfaces of illite and kaolinite. The presence of HDTMA $^{+}$cation micelles on the quartz surface was probably responsible for the strong affinity of $\mathrm{Cr}(\mathrm{VI})$ anions to the surface of red clay. The occurrence of surfactant micelles, apart from the bilayer of surfactant cations, is rather unquestionable taking into account the ratio of surfactant concentration in adsorbent to the maximum $\mathrm{Cr}(\mathrm{VI})$ concentration [12].

Metal adsorption onto hydrous solids such as metal oxides and clay minerals is a surface coordination process that can be modeled thermodynamically as a complex reaction between surface sites and adsorbate. The developed surface sites for a hydrated adsorbate are formulated as following expressions:

$$
\begin{aligned}
& \mathrm{S}-\mathrm{OH}_{2}^{+} \leftrightarrow \mathrm{S}-\mathrm{OH}+\mathrm{H}^{+} \\
& \mathrm{S}-\mathrm{OH} \leftrightarrow \mathrm{S}^{-} \mathrm{O}^{-}+\mathrm{H}^{+}
\end{aligned}
$$

where $\mathrm{S}$ represents the spent activated clay surface sites accounting for both Si- and Al- surfaces, and $\mathrm{S}-\mathrm{OH}_{2}^{+}$, $\mathrm{S}-\mathrm{OH}$ and $\mathrm{S}^{-} \mathrm{O}^{-}$refer to protonated, neutral and deprotonated surface hydroxyl functional groups, respectively. It is well known that $\mathrm{pH}_{\mathrm{zpc}}$ is a master variable to characterize the deprotonation of the amphoteric surface functional groups. In this work, at $\mathrm{pH}$ value below $\mathrm{pH}_{\mathrm{zpc}}$, the positively charged SAC surface $\left(\mathrm{S}^{-} \mathrm{OH}_{2}^{+}\right)$would be favorable for the anionic hydrochromate, $\mathrm{HCrO}_{4}^{-}$, adsorption whereupon the coulombic interaction forces can readily take place. Note that the hydro-chromate,

$\mathrm{HCrO}_{4}^{-}$, ion is the dominant species involved in the formation of surface complexes below $\mathrm{pH}_{\mathrm{zpc}}$.

Hence, the adsorption capacity of $\mathrm{HCrO}_{4}^{-}$will decrease due to the decrease of attractive surface charge of spent active clay. A small amount of $\mathrm{Cr}(\mathrm{VI})$ was removed between $\mathrm{pH} 3.8$ and 7.0 whereupon $\mathrm{pH}$ is greater than $\mathrm{pH}_{\mathrm{zpc}}$. At this region, the neutral surface hydroxyl functional group, $\mathrm{S}-\mathrm{OH}$, may be the sole active site providing for both $\mathrm{HCrO}_{4}^{-}$and $\mathrm{CrO}_{4}^{2-}$ adsorption.

As the solution $\mathrm{pH}$ increases, not only is less functional group ( $\mathrm{S}-\mathrm{OH})$ deprotonated but also more $\mathrm{OH}^{-}$is now competing with the coexistence of $\mathrm{HCrO}_{4}^{-}$and $\mathrm{CrO}_{4}^{2-}$ ions for the active surface sites. Consequently, it is difficult for them to form complexes and the adsorbed amount will decrease. In Table 3 the interaction between $\mathrm{Cr}(\mathrm{VI})$ and some adsorbents are presented.

Thus, the possible mechanisms for the $\mathrm{pH}$-dependent $\mathrm{Cr}(\mathrm{VI})$ adsorption onto spent active clay are proposed as follows:

$$
\begin{aligned}
& \mathrm{S}-\mathrm{OH}^{2+}+\mathrm{HCrO}_{4}^{-} \leftrightarrow \mathrm{S}^{-} \mathrm{HCrO}_{4}+\mathrm{H}_{2} \mathrm{O} \\
& \text { For } \mathrm{pH}<\mathrm{pH}_{\mathrm{zpc}}
\end{aligned}
$$




$$
\begin{aligned}
& \mathrm{S}-\mathrm{OH}+\mathrm{HCrO}_{4}^{-} \leftrightarrow \mathrm{S}-\mathrm{HCrO}_{4}+\mathrm{OH}^{-} ; \\
& \text {For } \mathrm{pH}<\mathrm{pH}_{\mathrm{zpc}} \\
& \mathrm{S}-\mathrm{OH}+\mathrm{CrO}_{4}^{2-} \leftrightarrow \mathrm{S}_{-} \mathrm{CrO}_{4}^{-}+\mathrm{OH}^{-} ; \\
& \text {For } \mathrm{pH}>\mathrm{pH}_{\mathrm{zpc}}
\end{aligned}
$$

where $\mathrm{S}-\mathrm{HCrO}_{4}$ and $\mathrm{S}_{-} \mathrm{CrO}_{4}^{-}$are the formation of the bonding complexes [13].

\section{Silica}

Silica $\left(\mathrm{SiO}_{2}\right)$ is a very common mineral due to the abundance of silicon and oxygen in nature, some silica properties are described in Table 4 [14]. Free silica occurs in many crystalline forms with compositions very close to that of pure silicon dioxide: $46.75 \mathrm{wt} \%$ silicon and 53.25 $w t \%$ oxygen. Quartz is by far the most common form. Tridymite, cristobalite, and the hydrous silica mineral opal are rare, as are vitreous (glassy) silica, coesite and stishovite. Several other forms have been produced in the laboratory but have not been found in nature [5].

Silica produced in the laboratory is a polymer of silicic acid, consisting of inter-linked tetrahedral $\mathrm{SiO}_{4}$, which has the stoichiometry $\mathrm{SiO}_{2}$. Silica gel is a porous, granular form of silica tetrachloride or substituted chlorosilane/orthisilicate. The sol-gel route is a versatile method for silica synthesis. In a sol-gel process hydrolysis of sodium silicate or alkoxysilane in presence of acid or base produces $\mathrm{Si}-(\mathrm{OH})_{4}$ entities, which on controlled condensation result in a sol. the active silica surface with large specific surface area is of great importance in adsorption and ion exchange. These properties are well studied, even though the shape of the silica surface is basically unknown. The method involving direct meas-

\begin{tabular}{|c|c|c|c|c|}
\hline Adsorbent & $\mathrm{pH}$ & Experimental conditions & Adsorption capacity $\left(\mathrm{mg} \cdot \mathrm{g}^{-1}\right)$ & Reference \\
\hline Kaolinite & 4.6 & $\begin{array}{l}2 \mathrm{~g} \text { sorbent } 1000 \mathrm{~mL} \text { solution } \\
{[\mathrm{Cr}(\mathrm{VI})]=0.1 \mathrm{mmol} \cdot \mathrm{L}^{-1}}\end{array}$ & $6.1 \mathrm{mg} \cdot \mathrm{g}^{-1}$ & {$[10]$} \\
\hline Acid-activated kaolinite & 4.6 & $\begin{array}{l}2 \mathrm{~g} \text { sorbent } 1000 \mathrm{~mL} \text { solution } \\
{[\mathrm{Cr}(\mathrm{VI})]=0.1 \mathrm{mmol} \cdot \mathrm{L}^{-1}}\end{array}$ & $8.0 \mathrm{mg} \cdot \mathrm{g}^{-1}$ & [10] \\
\hline Poly(oxozirconium) kaolinite & 4.6 & $\begin{array}{l}2 \mathrm{~g} \text { sorbent } 1000 \mathrm{~mL} \text { solution } \\
{[\mathrm{Cr}(\mathrm{VI})]=0.1 \mathrm{mmol} \cdot \mathrm{L}^{-1}}\end{array}$ & $5.6 \mathrm{mg} \cdot \mathrm{g}^{-1}$ & {$[10]$} \\
\hline Tetrabutylammonium kaolinite & 4.6 & $\begin{array}{l}2 \mathrm{~g} \text { sorbent } 1000 \mathrm{~mL} \text { solution } \\
{[\mathrm{Cr}(\mathrm{VI})]=0.1 \mathrm{mmol} \cdot \mathrm{L}^{-1}}\end{array}$ & $5.4 \mathrm{mg} \cdot \mathrm{g}^{-1}$ & {$[10]$} \\
\hline Red clay & $4-6.5$ & $\begin{array}{l}0.4 \mathrm{~g} \text { sorbent } 100 \mathrm{~mL} \text { solution } \\
{[\mathrm{Cr}(\mathrm{VI})]=0.1-10 \mathrm{mmol} \cdot \mathrm{L}^{-1}}\end{array}$ & $1.3 \mathrm{mg} \cdot \mathrm{g}^{-1}$ & [12] \\
\hline Red clay—modified with HDTMA & $4-6.5$ & $\begin{array}{l}0.4 \mathrm{~g} \text { sorbent } 100 \mathrm{~mL} \text { solution } \\
{[\mathrm{Cr}(\mathrm{VI})]=0.1-10 \mathrm{mmol} \cdot \mathrm{L}^{-1}}\end{array}$ & $4.3 \mathrm{mg} \cdot \mathrm{g}^{-1}$ & {$[12]$} \\
\hline Spent activated clay & 2 & $\begin{array}{l}0.1 \mathrm{~g} \text { sorbent } 30 \mathrm{~mL} \text { solution } \\
{[\mathrm{Cr}(\mathrm{VI})]=0.13 \mathrm{mmol} \cdot \mathrm{L}^{-1}}\end{array}$ & $1.422 \mathrm{mg} \cdot \mathrm{g}^{-1}$ & [13] \\
\hline
\end{tabular}
urement (imaging) of the outer surface of silica or modified silica is atomic force microscopy (AFM), which is

Table 3. Results of Chromium(VI) removal with natural and modified clays.

Table 4. Properties of silica minerals.

\begin{tabular}{cll}
\hline Name & Crystal system & Remarks \\
\hline Low quartz (alpha-quartz) & Hexagonal & Common form of silica \\
High quartz (beta-quartz) & Hexagonal & Metastable above $870^{\circ} \mathrm{C}$ \\
Low tridymite & Orthorhombic & Exists metastably up to $117^{\circ} \mathrm{C}$ \\
Middle tridymite & Hexagonal & Exists metastably between to $117^{\circ} \mathrm{C}$ and $163^{\circ} \mathrm{C}$ \\
High tridymite & Hexagonal & Exists metastably from $163^{\circ} \mathrm{C}$ to $870^{\circ} \mathrm{C}$; unstable over $1470^{\circ} \mathrm{C}$; melts at $1670^{\circ} \mathrm{C}$ \\
Low cristobalite & Tetragonal & Exists metastably up to $200^{\circ} \mathrm{C}-250^{\circ} \mathrm{C}$ \\
High cristobalite & Isometric & Exists metastably from $200^{\circ} \mathrm{C}-250^{\circ} \mathrm{C}$ to $1470^{\circ} \mathrm{C}$; melts at $1713^{\circ} \mathrm{C}$ \\
Keatite & Tetragonal & Not yet found in nature; high-pressure phase \\
Coesite & Monoclinic & Characteristic mineral of meteorictic shock; high-pressure phase \\
Stishovite & Tetragonal & \\
Vitreous silica & Amorphous & Unstable glass below $1713^{\circ} \mathrm{C}$ \\
Opal & Poorly crystalline or amorphous & \\
\hline
\end{tabular}

Source: [5]. 
based on scanning of the surface with a special probe. At the surface, the structure terminates in either siloxane group ( $\equiv \mathrm{Si}-\mathrm{O}-\mathrm{Si} \equiv$ ) with the oxygen atom on the surface, or one of the several forms of silanol groups ( $\equiv \mathrm{Si}-\mathrm{OH})$. The silanol groups can be isolated (free silanol groups), where the surface silicon atom has three bonds into the bulk structure and the fourth to $\mathrm{OH}$ group and the vicinal or bridged silanols, where two isolated silanol groups attached to two different silicon atoms are bridged by H-bond. A third type of silanols called geminal silanols consists of two hydroxyl groups attached to one silicon atom. The geminal silanols are close enough to have $\mathrm{H}$-bond whereas free silanols are too far separated as indicated in Figure 2 [15].

\section{Surface Modification of Silica Gel}

Modification of the silica surface relates to all the processes that lead to change in chemical composition of the surface. Surfaces can be modified either by physical treatment (thermal or hydrothermal) that leads to a change in ratio of silanol and siloxane or by chemical treatment that leads to change in chemical characteristics of silica surface. Modifications significantly affect the adsorption properties of the material. Chemisorption of chelating molecules on a silica surface provides immobility, mechanical stability and water insolubility, thereby increasing the efficiency, sensitivity and selectivity of the analytical application. A silica gel surface can be modified by two distinct processes: organofunctionalization, where the modifying agent is an organic group, and inorganofunctionalization, in which the group anchored on the surface can be an organometallic composite or a metallic oxide. The most convenient way to develop a chemically modified surface is achieved by simple immobilization (or fixing) of the group on the surface by adsorption or electrostatic interaction or hydrogen bond formation or other type of interaction [15].

Heavy metals are effectively removed by silica compounds functionalized with carboxylic acids, sulfonic acids and quaternary ammonium groups. The support for these groups is often silica-based, because silica provides chemical resistance and is mechanically robust. Silica-based support structures are widely used in the field of selective separations because of their well-known acid and solvent stability, as well as their excellent mechani- cal properties and do not have the shrink/swell characteristics. Chromium removal by a LaSiCS composite was mainly governed by adsorption mechanism. The positively charged $\mathrm{La}^{3+}$ surface in the hybrid composite attracts the negatively charged chromium ions by means of electrostatic attraction. The chromium removal by $\mathrm{Si}$ is mainly due to its porous nature which entraps chromium by means of electrostatic attraction. The strong electrostatic adsorption and complexation between $\mathrm{La}^{3+}$ and $\mathrm{HCrO}_{4}^{-}$ion are mainly responsible for the significant enhanced adsorption capacities of the $\mathrm{La}$ (III) incorporated hybrid composite. The reactive $-\mathrm{OH}$ and $-\mathrm{NH}_{2}$ electron donor groups present in the LaSiCS composite reduce the $\mathrm{Cr}(\mathrm{VI})$ to less toxic $\mathrm{Cr}(\mathrm{III})$ in an adsorption coupled reduction.

The effect of $\mathrm{pH}$ on the sorption of $\mathrm{Cr}(\mathrm{VI})$ onto the sorbents is higher at low $\mathrm{pH}$ and decreases with increasing $\mathrm{pH}$. The reason could be that at lower $\mathrm{pH}$, the sorbents acquire a positive charge due to the protonation of amino groups and that the predominant species of chromium is $\mathrm{HCrO}_{4}^{-}$. There is a gradual decrease in the adsorption capacities of the sorbents as the $\mathrm{pH}$ of the solution increases, which may be due to the competition of $\mathrm{OH}^{-}$ion for the sorption sites of the sorbent surface [16]. The adsorption capacity of the natural and modified silica is shown in Table 5.

\section{Zeolites}

A zeolite is a crystalline mineral with a structure characterized by a framework of linked tetrahedrals, each consisting of four oxygen atoms surrounding a cation. This framework contains open cavities in the form of channels and cages. They are usually occupied by water molecules and extra-framework cations that are commonly exchangeable and are large enough to allow the passage of guest species. In hydrated phases, dehydration occurs at temperatures mostly below about $400^{\circ} \mathrm{C}$ and is largely reversible. The framework may be interrupted by hydroxyl

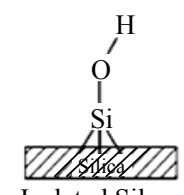

Isolated Silanol
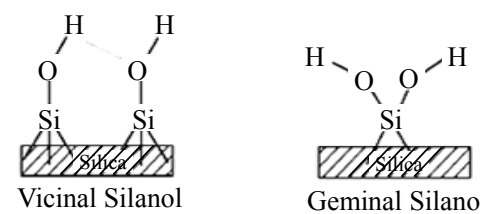

Geminal Silanol

Figure 2. Silanol groups. Source: [15].

Table 5. Results of chromium(VI) removal with silica.

\begin{tabular}{|c|c|c|c|c|}
\hline Adsorbent & $\mathrm{pH}$ & Experimental Conditions & Adsorption capacity $\left(\mathrm{mg} \cdot \mathrm{g}^{-1}\right)$ & Reference \\
\hline Silica & $2-4$ & $0.1 \mathrm{~g}$ sorbent $50 \mathrm{~mL}$ solution $[\mathrm{Cr}(\mathrm{VI})]=10 \mathrm{mg} \cdot \mathrm{L}^{-1}$ & $1.5 \mathrm{mg} \cdot \mathrm{g}^{-1}$ & {$[16]$} \\
\hline Silica-Chitosan & $2-4$ & $0.1 \mathrm{~g}$ sorbent $50 \mathrm{~mL}$ solution $[\mathrm{Cr}(\mathrm{VI})]=10 \mathrm{mg} \cdot \mathrm{L}^{-1}$ & $4.0 \mathrm{mg} \cdot \mathrm{g}^{-1}$ & {$[16]$} \\
\hline La(III) Silica-Chitosan & $2-4$ & $0.1 \mathrm{~g}$ sorbent $50 \mathrm{~mL}$ solution $[\mathrm{Cr}(\mathrm{VI})]=10 \mathrm{mg} \cdot \mathrm{L}^{-1}$ & $5.5 \mathrm{mg} \cdot \mathrm{g}^{-1}$ & {$[16]$} \\
\hline
\end{tabular}


or flour groups which occupy a tetrahedron apex that is not shared with the adjacent tetrahedral [17]. Natural zeolites are hydrated crystalline aluminosilicate minerals with uniform pore size that are based on three dimensional network of $\mathrm{AlO}_{4}$ and $\mathrm{SiO}_{4}$ tetrahedrally linked to each other by sharing oxygens [2,18].

Zeolites to be elevated to series status and the conesquential new species to be recognized on the basis of the most abundant extra-framework cation are set out in Table 6.

Zeolites are structures containing an interrupted framework of silica and alumina tetrahedrals, but can

Table 6. Classification of zeolites.

\begin{tabular}{|c|c|}
\hline Name & Chemical composition \\
\hline \multicolumn{2}{|l|}{ Group 1 (S4R) } \\
\hline Analcime & $\mathrm{Na}_{16}\left[\left(\mathrm{AlO}_{2}\right)_{16}\left(\mathrm{SiO}_{2}\right)_{32}\right] \cdot 16 \mathrm{H}_{2} \mathrm{O}$ \\
\hline Harmotome & $\mathrm{Ba}_{2}\left[\left(\mathrm{AlO}_{2}\right)_{4}\left(\mathrm{SiO}_{2}\right)_{12}\right] \cdot 12 \mathrm{H}_{2} \mathrm{O}$ \\
\hline Phillipsite & $(\mathrm{K}, \mathrm{Na})_{10}\left[\left(\mathrm{AlO}_{2}\right)_{10}\left(\mathrm{SiO}_{2}\right)_{22}\right] \cdot 20 \mathrm{H}_{2} \mathrm{O}$ \\
\hline Gismondine & $\mathrm{Ca}_{4}\left[\left(\mathrm{AlO}_{2}\right)_{8}\left(\mathrm{SiO}_{2}\right)_{8}\right] \cdot 16 \mathrm{H}_{2} \mathrm{O}$ \\
\hline $\mathrm{P}$ & $\mathrm{Na}_{6}\left[\left(\mathrm{AlO}_{2}\right)_{6}\left(\mathrm{SiO}_{2}\right)_{10}\right] \cdot 15 \mathrm{H}_{2} \mathrm{O}$ \\
\hline Paulingite & $\left.\left.\mathrm{K}_{2}, \mathrm{Na}, \mathrm{Ca}, \mathrm{Ba}\right)_{76}\left[\mathrm{AlO}_{2}\right)_{152}\left(\mathrm{SiO}_{2}\right)_{520}\right] \cdot 700 \mathrm{H}_{2} \mathrm{O}$ \\
\hline Laumontite & $\mathrm{Ca}_{4}\left[\left(\mathrm{AlO}_{2}\right)_{8}\left(\mathrm{SiO}_{2}\right)_{46}\right] \cdot 16 \mathrm{H}_{2} \mathrm{O}$ \\
\hline Yugawaralie & $(\mathrm{K}, \mathrm{Na})_{10}\left[\left(\mathrm{AlO}_{2}\right)_{10}\left(\mathrm{SiO}_{2}\right)_{22}\right] \cdot 20 \mathrm{H}_{2} \mathrm{O}$ \\
\hline \multicolumn{2}{|l|}{ Group 2 (S6R) } \\
\hline Erionite & $\left(\mathrm{Ca}, \mathrm{Mg}, \mathrm{K}_{2}, \mathrm{Na}_{2}\right)_{4.3}\left[\left(\mathrm{AlO}_{2}\right)_{9}\left(\mathrm{SiO}_{2}\right)_{27}\right] \cdot 27 \mathrm{H}_{2} \mathrm{O}$ \\
\hline Offretite & $\left(\mathrm{K}_{2}, \mathrm{Ca}\right)_{2.7}\left[\left(\mathrm{AlO}_{2}\right)_{5.4}\left(\mathrm{SiO}_{2}\right)_{12.6}\right] \cdot 15 \mathrm{H}_{2} \mathrm{O}$ \\
\hline $\mathrm{T}$ & $\left(\mathrm{Na}_{1.2}, \mathrm{~K}_{2.8}\right)\left[\left(\mathrm{AlO}_{2}\right)_{4}\left(\mathrm{SiO}_{2}\right)_{14}\right] \cdot 14 \mathrm{H}_{2} \mathrm{O}$ \\
\hline Levynite & $\mathrm{Ca}_{3}\left[\left(\mathrm{AlO}_{2}\right)_{6}\left(\mathrm{SiO}_{2}\right)_{12}\right] \cdot 18 \mathrm{H}_{2} \mathrm{O}$ \\
\hline \multicolumn{2}{|r|}{ 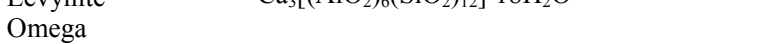 } \\
\hline \multirow[t]{3}{*}{ Hydrated Sodalite } & $\left(\mathrm{Na}_{6.8} \mathrm{TMA}_{1.6}\right)\left[\left(\mathrm{AlO}_{2}\right)_{8}\left(\mathrm{SiO}_{2}\right)_{28}\right] \cdot 21 \mathrm{H}_{2} \mathrm{O}$ \\
\hline & $\mathrm{Na}_{6}\left[\left(\mathrm{AlO}_{2}\right)_{6}\left(\mathrm{SiO}_{2}\right)_{6}\right] \cdot 7.5 \mathrm{H}_{2} \mathrm{O}$ \\
\hline & $\mathrm{Na}_{12}\left[\left(\mathrm{AlO}_{2}\right)_{12}\left(\mathrm{SiO}_{2}\right)_{12}\right] \cdot 19 \mathrm{H}_{2} \mathrm{O}$ \\
\hline \multicolumn{2}{|l|}{ Group 3 (D4R) } \\
\hline A & $\mathrm{Na}_{12}\left[\left(\mathrm{AlO}_{2}\right)_{12}\left(\mathrm{SiO}_{2}\right)_{12}\right] \cdot 27 \mathrm{H}_{2} \mathrm{O}$ \\
\hline $\mathrm{N}-\mathrm{a}$ & $\left(\mathrm{Na}_{4} \mathrm{TMA}_{3}\right)\left[\left(\mathrm{AlO}_{2}\right)_{7}\left(\mathrm{SiO}_{2}\right)_{17}\right] \cdot 21 \mathrm{H}_{2} \mathrm{O}$ \\
\hline ZK-4 & $\left(\mathrm{Na}_{8} \mathrm{TMA}_{1.6}\right)\left[\left(\mathrm{AlO}_{2}\right)_{8}\left(\mathrm{SiO}_{2}\right)_{15}\right] \cdot 28 \mathrm{H}_{2} \mathrm{O}$ \\
\hline \multicolumn{2}{|l|}{ Group 4 (D6R) } \\
\hline Faujasite & $\left(\mathrm{Na}_{2}, \mathrm{~K}_{2}, \mathrm{Ca}, \mathrm{Mg}\right)_{29.5}\left[\left(\mathrm{AlO}_{2}\right)_{59}\left(\mathrm{SiO}_{2}\right)_{133}\right] \cdot 235 \mathrm{H}_{2} \mathrm{O}$ \\
\hline $\mathrm{X}$ & $\mathrm{Na}_{86}\left[\left(\mathrm{AlO}_{2}\right)_{86}\left(\mathrm{SiO}_{2}\right)_{105}\right] \cdot 264 \mathrm{H}_{2} \mathrm{O}$ \\
\hline Y & $\mathrm{Na}_{56}\left[\left(\mathrm{AlO}_{2}\right)_{56}\left(\mathrm{SiO}_{2}\right)_{136}\right] \cdot 250 \mathrm{H}_{2} \mathrm{O}$ \\
\hline Chabazite & $\mathrm{Ca}_{2}\left[\left(\mathrm{AlO}_{2}\right)_{4}\left(\mathrm{SiO}_{2}\right)_{8} \cdot 13 \mathrm{H}_{2} \mathrm{O}\right.$ \\
\hline Gmelinite & $\mathrm{Na}_{8}\left[\left(\mathrm{AlO}_{2}\right)_{8}\left(\mathrm{SiO}_{2}\right)_{16}\right] \cdot 24 \mathrm{H}_{2} \mathrm{O}$ \\
\hline $\mathrm{ZK}-5$ & $\left(\mathrm{R}, \mathrm{Na}_{2}\right)_{15}\left[\left(\mathrm{AlO}_{2}\right)_{30}\left(\mathrm{SiO}_{2}\right)_{66}\right] \cdot 98 \mathrm{H}_{2} \mathrm{O}$ \\
\hline $\mathrm{L}^{\mathrm{R}}$ & $\mathrm{K}_{9}\left[\left(\mathrm{AlO}_{2}\right)_{9}\left(\mathrm{SiO}_{2}\right)_{27}\right] \cdot 22 \mathrm{H}_{2} \mathrm{O}$ \\
\hline \multicolumn{2}{|l|}{ Group $5\left(\mathrm{~T}_{5} \mathrm{O}_{10}\right)$} \\
\hline Natrolite & $\mathrm{Na}_{16}\left[\left(\mathrm{AlO}_{2}\right)_{16}\left(\mathrm{SiO}_{2}\right)_{24}\right] \cdot 16 \mathrm{H}_{2} \mathrm{O}$ \\
\hline Scolecite & $\mathrm{Ca}_{8}\left[\left(\mathrm{AlO}_{2}\right)_{16}\left(\mathrm{SiO}_{2}\right)_{24}\right] \cdot 16 \mathrm{H}_{2} \mathrm{O}$ \\
\hline Mesolite & $\left(\mathrm{Na}_{16} \mathrm{Ca}_{16}\right)\left[\left(\mathrm{AlO}_{2}\right)_{48}\left(\mathrm{SiO}_{2}\right)_{72}\right] \cdot 64 \mathrm{H}_{2} \mathrm{O}$ \\
\hline Thomsonite & $\left(\mathrm{Na}_{4} \mathrm{Ca}_{8}\right)\left[\left(\mathrm{AlO}_{2}\right)_{20}\left(\mathrm{SiO}_{2}\right)_{20}\right] \cdot 24 \mathrm{H}_{2} \mathrm{O}$ \\
\hline Gonnardite & $\left(\mathrm{Na}_{4} \mathrm{Ca}_{2}\right)\left[\left(\mathrm{AlO}_{2}\right)_{8}\left(\mathrm{SiO}_{2}\right)_{12}\right] \cdot 14 \mathrm{H}_{2} \mathrm{O}$ \\
\hline Edingtonite & $\mathrm{Ba}_{2}\left[\left(\mathrm{AlO}_{2}\right)_{4}\left(\mathrm{SiO}_{2}\right)_{6}\right] \cdot 8 \mathrm{H}_{2} \mathrm{O}$ \\
\hline \multicolumn{2}{|l|}{ Group $6\left(\mathrm{~T}_{8} \mathrm{O}_{16}\right)$} \\
\hline Mordenite & $\mathrm{Na}_{8}\left[\left(\mathrm{AlO}_{2}\right)_{8}\left(\mathrm{SiO}_{2}\right)_{40}\right] \cdot 24 \mathrm{H}_{2} \mathrm{O}$ \\
\hline Dachiardite & $\mathrm{Na}_{5}\left[\left(\mathrm{AlO}_{2}\right)_{5}\left(\mathrm{SiO}_{2}\right)_{19}\right] \cdot 12 \mathrm{H}_{2} \mathrm{O}$ \\
\hline Ferrierite & $\left(\mathrm{Na}_{1.5}, \mathrm{Mg}_{2}\right)\left[\left(\mathrm{AlO}_{2}\right)_{5.5}\left(\mathrm{SiO}_{2}\right)_{30.5}\right] \cdot 18 \mathrm{H}_{2} \mathrm{O}$ \\
\hline Epistilbite & $\mathrm{Ca}_{3}\left[\left(\mathrm{AlO}_{2}\right)_{6}\left(\mathrm{SiO}_{2}\right)_{18}\right] \cdot 18 \mathrm{H}_{2} \mathrm{O}$ \\
\hline Bikitaite & $\mathrm{Li}_{2}\left[\left(\mathrm{AlO}_{2}\right)_{2}\left(\mathrm{SiO}_{2}\right)_{4}\right] \cdot 2 \mathrm{H}_{2} \mathrm{O}$ \\
\hline \multicolumn{2}{|l|}{ Group $7\left(\mathrm{~T}_{10} \mathrm{O}_{20}\right)$} \\
\hline Heulandita & $\mathrm{Ca}_{4}\left[\left(\mathrm{AlO}_{2}\right)_{8}\left(\mathrm{SiO}_{2}\right)_{28}\right] \cdot 24 \mathrm{H}_{2} \mathrm{O}$ \\
\hline Clinoptilolita & $\mathrm{Na}_{6}\left[\left(\mathrm{AlO}_{2}\right)_{6}\left(\mathrm{SiO}_{2}\right)_{30}\right] \cdot 24 \mathrm{H}_{2} \mathrm{O}$ \\
\hline Stilbita & $\mathrm{Ca}_{4}\left[\left(\mathrm{AlO}_{2}\right)_{8}\left(\mathrm{SiO}_{2}\right)_{28}\right] \cdot 28 \mathrm{H}_{2} \mathrm{O}$ \\
\hline Brewsterita & $(\mathrm{Sr}, \mathrm{Ba}, \mathrm{Ca})_{2}\left[\left(\mathrm{AlO}_{2}\right)_{4}\left(\mathrm{SiO}_{2}\right)_{12}\right] \cdot 10 \mathrm{H}_{2} \mathrm{O}$ \\
\hline
\end{tabular}

Source: [19]. include substitution by elements other than $\mathrm{Si}$ and $\mathrm{Al}$. Separate species are recognized in topologically distinctive compositional series in which different extra-framework cations are the most abundant in atomic proportions. Zeolite species are not to be distinguished solely on the ratio $\mathrm{Si}: \mathrm{Al}$ except for heulandite $(\mathrm{Si}: \mathrm{Al}<4.0)$ and clinoptilolite $(\mathrm{Si}: \mathrm{Al}>4.0)$. Dehydration, partial hydration, and overhydration are not sufficient grounds for the recognition of separate species of zeolites. Use of the term "ideal formula" should be avoided in referring to a simplified or averaged formula of a zeolite. Newly recognized species in compositional series are as follows: brewsterite-Sr, -Ba, chabazite-Ca, -Na, $-\mathrm{K}$, clinoptilolite-K, $-\mathrm{Na},-\mathrm{Ca}$, dachiardite-Ca, $-\mathrm{Na}$, erionite- $\mathrm{Na},-\mathrm{K},-\mathrm{Ca}$, faujasite-Na, -Ca, $-\mathrm{Mg}$, ferrierite-Mg, $-\mathrm{K},-\mathrm{Na}$, gmelinite- $\mathrm{Na},-\mathrm{Ca},-\mathrm{K}$, heulandite- $\mathrm{Ca},-\mathrm{Na},-\mathrm{K}$, -Sr, levyne-Ca, -Na, paulingite-K, -Ca, phillipsite-Na, $-\mathrm{Ca},-\mathrm{K}$, and stilbite-Ca, -Na (see Table 7) [17].

There are more than 30 natural zeolites known, but only seven (mordenite, clinoptilolite, chabazite, erionite, ferrierite, phillipsite, and analcime) occur in sufficient quantity and purity to be considered exploitable [8].

The most important properties of zeolites are uniform pore size, reversible hydration and ion exchange [2,21]. Zeolites, modified by ion exchange, can be used for adsorption of different metal ions [8]. Zeolites possess a net negative structural charge, resulting from isomorphic substitution of cations in the crystal lattice. This permanent negative charge results in the favorable ion exchange selectivity of zeolites for certain cations [4].

Most of the naturally occurring zeolites have negative charges on their external surfaces, which prevents sorption and retention of anions, but efforts have been made to convert the surface charges from negative to positive by surface modification. Cationic surfactants have been used extensively for modification of clay minerals and zeolites [9].

Clinoptilolite is the most abundant natural zeolite of the Heulandite group [21]. Its characteristic tabular morphology shows an open reticular structure formed by open channels of 8 - 10 membered rings. It includes exchangeable ions such as $\mathrm{Na}(\mathrm{I}), \mathrm{K}(\mathrm{I}), \mathrm{Ca}(\mathrm{II})$ and $\mathrm{Mg}(\mathrm{II})$ [22]. The reported composition is indicated in Table 8.

Table 7. Composition of zeolites.

\begin{tabular}{cc}
\hline Component & Percent \\
\hline $\mathrm{SiO}_{2}$ & $35.58 \%$ \\
$\mathrm{Al}_{2} \mathrm{O}_{3}$ & $28.07 \%$ \\
$\mathrm{Na}_{2} \mathrm{O}$ & $17.21 \%$ \\
$\mathrm{SO}_{3}$ & $1.08 \%$ \\
$\mathrm{LOI}$ & $17.53 \%$ \\
\hline
\end{tabular}

Source: [20]. 


\section{Modification of Zeolites with Cationic Surfactants}

The negative charge on their external surfaces results in the favorable ion exchange selectivity of zeolites for certain cations, but causes them to have little or no affinity for anions [4]. Some heavy metals like chromium are present as cations, anions, or non-ionized species. Hence, development of materials with the capability to adsorb anions, cations, and neutral molecules is very important. Zeolites can be treated with cationic surfactants in order to do this. Through treatment, an organic layer is created on the external surfaces and the charge is reversed to positive [20]. These cationic surfactants increase the fractional organic carbon content in order to enhance the sorption of non-polar hydrophobic organic contaminants. It was observed that the longer the tail group of the cationic surfactant, the more stable the surfactant retained on the surface [3].

Chromium(VI) sorption was performed at different $\mathrm{pH}$ values. At neutral $\mathrm{pH}$ chromium is present in the form of $\mathrm{CrO}_{4}^{2-}$ which is a stable form of $\mathrm{Cr}(\mathrm{VI})$. However, at lower $\mathrm{pH}$ dichromate ions are formed which have a larger particle size than chromate ions. The pore size of zeolite is more suitable for the sorption of $\mathrm{CrO}_{4}{ }^{2-}$ ions than the $\mathrm{Cr}_{2} \mathrm{O}_{7}^{2-}$ ions [24].

$$
\mathrm{HCrO}_{4}^{-} \leftrightarrow \mathrm{CrO}_{4}^{2-}+\mathrm{H}^{+}
$$

$$
\begin{aligned}
& \mathrm{H}_{2} \mathrm{CrO}_{4} \leftrightarrow \mathrm{HCrO}_{4}^{-}+\mathrm{H}^{+} \\
& \mathrm{Cr}_{2} \mathrm{O}_{7}+\mathrm{H}_{2} \mathrm{O} \leftrightarrow \mathrm{HCrO}_{4}^{-}
\end{aligned}
$$

Quaternary amines such as hexadecyltrimetylammonium (HDTMA) are tetrasubtituted ammonium salts with a permanently charged pentavalent nitrogen and at least one alkyl chain. HDTMA is strongly surface active and contains a long straight alkyl chain (C16) which imparts a high degree of hydrophobicity. A general model of sorption of cationic surfactants on a solid surface can be explained by formation of a monolayer or hemimicela in the solid-liquid interface via ionic bonding, in concentrations of surfactant equal to or below its critical micelle concentration (CMC). At higher concentrations of the solution, the surfactant molecules can be absorbed by interactions with the alkyl chain, forming a bilayer or admicel [25]. The $\mathrm{Cr}(\mathrm{VI})$ interaction with natural and modified zeolites are presented in Table 9.

Table 8. Composition of clinoptilolite.

\begin{tabular}{lccc}
\hline $\begin{array}{l}\text { Mineralogical } \\
\text { Composition }\end{array}$ & Percent & $\begin{array}{c}\text { Chemical } \\
\text { Composition }\end{array}$ & Percent \\
\hline Clinoptilolite & $80 \%$ & $\mathrm{SiO}_{2}$ & $55.80 \%$ \\
$\begin{array}{l}\text { Mordenite } \\
\text { Quartz, Feldspart, }\end{array}$ & $5 \%$ & $\mathrm{Al}_{2} \mathrm{O}_{3}$ & $13.32 \%$ \\
Montmorillonie and Illite & $15 \%$ & $\mathrm{CaO}$ & $5.75 \%$ \\
\hline
\end{tabular}

\begin{tabular}{|c|c|c|c|c|}
\hline Adsorbent & $\mathrm{pH}$ & Experimental Conditions & Adsorption capacity $\left(\mathrm{mg} \cdot \mathrm{g}^{-1}\right)$ & Reference \\
\hline Zeolite HDTM & 6 & $\begin{array}{l}0.5 \text { g sorbent } 25 \mathrm{~mL} \text { solution } \\
{[\mathrm{Cr}(\mathrm{VI})]=15 \mathrm{mmol} \cdot \mathrm{mL}^{-1}}\end{array}$ & $39.47 \mathrm{mg} \cdot \mathrm{g}^{-1}$ & {$[2]$} \\
\hline Zeolite TBA & 6 & $\begin{array}{l}0.5 \mathrm{~g} \text { sorbent } 25 \mathrm{~mL} \text { solution } \\
{[\mathrm{Cr}(\mathrm{VI})]=15 \mathrm{mg} \cdot \mathrm{mL}^{-1}}\end{array}$ & $29.5 \mathrm{mg} \cdot \mathrm{g}^{-1}$ & {$[2]$} \\
\hline Clinoptilolite exchanged various metal cations & $\begin{array}{l}4.5 \\
7.5 \\
7.2 \\
6.3 \\
6.5 \\
7.2 \\
4.5\end{array}$ & $\begin{array}{l}2 \mathrm{~g} 50 \mathrm{~mL} \text { solution } \\
{[\mathrm{Cr}(\mathrm{VI})]=10-100 \mathrm{mmol} \cdot \mathrm{L}^{-1}}\end{array}$ & $\begin{array}{l}\mathrm{Pb}=0.560 \mathrm{mg} \cdot \mathrm{g}^{-1} \\
\mathrm{Ag}=410 \mathrm{mg} \cdot \mathrm{g}^{-1} \\
\mathrm{Ba}=0.340 \mathrm{mg} \cdot \mathrm{g}^{-1} \\
\mathrm{Hg}=0.360 \mathrm{mg} \cdot \mathrm{g}^{-1} \\
\mathrm{Sr}=0.210 \mathrm{mg} \cdot \mathrm{g}^{-1} \\
\mathrm{Ca}=0.210 \mathrm{mg} \cdot \mathrm{g}^{-1} \\
\mathrm{Clip}=0.006 \mathrm{mg} \cdot \mathrm{g}^{-1}\end{array}$ & [4] \\
\hline Modified Nanozeolite A HDTMA-Br & 3.0 & $\begin{array}{l}0.25 \mathrm{~g} \text { sorbent } 50 \mathrm{~mL} \text { solution } \\
{[\mathrm{Cr}(\mathrm{VI})]=1.0 \mathrm{mg} \cdot \mathrm{L}^{-1}}\end{array}$ & $14.16 \mathrm{mg} \cdot \mathrm{g}^{-1}$ & {$[20]$} \\
\hline Clinoptilolite modified with BrHDTMA & 2 & $\begin{array}{l}0.1 \text { g sorbent } 30 \mathrm{~mL} \text { solution } \\
{[\mathrm{Cr}(\mathrm{VI})]=0.4 \mathrm{mmol} \cdot \mathrm{L}^{-1}}\end{array}$ & $3.83 \mathrm{mg} \cdot \mathrm{g}^{-1}$ & {$[23]$} \\
\hline HDTMA-Modified Zeolites (Erionite) & 7.0 & $\begin{array}{l}0.1 \mathrm{~g} \text { sorbent } 50 \mathrm{~mL} \text { solution } \\
{[\mathrm{Cr}(\mathrm{VI})]=2.0 \mathrm{mmol} \cdot \mathrm{L}^{-1}}\end{array}$ & $0.103 \mathrm{mg} \cdot \mathrm{g}^{-1}$ & {$[24]$} \\
\hline HDTMA-Modified Zeolites Cowlesite & 7.0 & $\begin{array}{l}0.1 \mathrm{~g} \text { sorbent } 50 \mathrm{~mL} \text { solution } \\
{[\mathrm{Cr}(\mathrm{VI})]=2.0 \mathrm{mmol} \cdot \mathrm{L}^{-1}}\end{array}$ & $0.763 \mathrm{mg} \cdot \mathrm{g}^{-1}$ & {$[26]$} \\
\hline HDTMA-Modified Zeolites Willhendersonite & 7.0 & $\begin{array}{l}0.1 \text { g sorbent } 50 \mathrm{~mL} \text { solution } \\
{[\mathrm{Cr}(\mathrm{VI})]=2.0 \mathrm{mmol} \cdot \mathrm{L}^{-1}}\end{array}$ & $0.719 \mathrm{mg} \cdot \mathrm{g}^{-1}$ & {$[26]$} \\
\hline $\begin{array}{l}\text { Clinoptilolite modified with } \\
\text { hexadecyltrimethylammonium (C16) }\end{array}$ & $2.6-3.1$ & $\begin{array}{l}20 \mathrm{mg} \text { sorbent } 10 \mathrm{~mL} \text { solution } \\
{[\mathrm{Cr}(\mathrm{VI})]=0.2-6.24 \mathrm{mmol} \cdot \mathrm{L}^{-1}}\end{array}$ & $0.124 \mathrm{mg} \cdot \mathrm{g}^{-1}$ & {$[27]$} \\
\hline $\begin{array}{l}\text { Clinoptilolite modified with } \\
\text { dioctadecyldimethylammonium }(2 \mathrm{C} 18)\end{array}$ & $2.6-3.1$ & $\begin{array}{l}20 \mathrm{mg} \text { sorbent } 10 \mathrm{~mL} \text { solution } \\
{[\mathrm{Cr}(\mathrm{VI})]=0.2-6.24 \mathrm{mmol} \cdot \mathrm{L}^{-1}}\end{array}$ & $0.103 \mathrm{mg} \cdot \mathrm{g}^{-1}$ & {$[27]$} \\
\hline Clinoptilolite & 3.0 & $\begin{array}{l}0.5 \mathrm{~g} \text { sorbent } 50 \mathrm{~mL} \text { solution } \\
{[\mathrm{Cr}(\mathrm{VI})]=10 \mathrm{mmol} \cdot \mathrm{L}^{-1}}\end{array}$ & $19.9 \mathrm{mg} \cdot \mathrm{g}^{-1}$ & {$[28]$} \\
\hline Clinoptilolite-ODA & 3.0 & $\begin{array}{l}0.5 \mathrm{~g} \text { sorbent } 50 \mathrm{~mL} \text { solution } \\
{[\mathrm{Cr}(\mathrm{VI})]=10 \mathrm{mmol} \cdot \mathrm{L}^{-1}}\end{array}$ & $54 \mathrm{mg} \cdot \mathrm{g}^{-1}$ & {$[28]$} \\
\hline Clinoptilolite HDTMA & 7 & $\begin{array}{l}1 \mathrm{~g} \text { sorbent } 25 \mathrm{~mL} \text { solution } \\
{[\mathrm{Cr}(\mathrm{VI})]=4 \mathrm{mmol} \cdot \mathrm{L}^{-1}}\end{array}$ & $0.844 \mathrm{mg} \cdot \mathrm{g}^{-1}$ & [29] \\
\hline
\end{tabular}

Sources: [4,23].

Table 9. Results of chromium(VI) removal with natural and modified zeolites. 


\section{Conclusions}

Today there exists a problem of water pollution with heavy metals, this problem has led to the search of techniques and materials that are environmentally friendly and that can be used to remove heavy metals. Chromium Hexavalent is one the most important pollutants. There are a number of available technologies for the remediation of chromium, but none of them is applicable to all situations.

The adsorption has proven a useful tool to control the degree of contamination of chromium in the water. Low cost materials have an adsorption capacity. Some studies have been shown the applicability of inorganic materials such as clay minerals, silica and zeolites as sorbents heavy metal ions and the chemical modification of these material surfaces by using chemical ligating groups providing increased capacity for trapping metal ions specifically and selectively even at trace level. Such studies have been limited to evaluate the capacity of adsorption solution but it is necessary to continue studies at pilot plant scale for knowing their true scope.

\section{REFERENCES}

[1] Y. Kubota, "Effect of Zeolite Modification for Chromate Adsorption by Using Mongolian Natural Zeolite. Bachelor Dissertation," Department of International Development Engineering, Tokyo Institute of Technology, Tokyo, 2009.

[2] P. D. Kumar, S. Jadhav, S. Rayalu and S. Devotta, "Surface-Modified Zeolite-A for Sequestration of Arsenic and Chromium Anions," Current Science, Vol. 92, No. 4, 2007, pp. 512-517.

[3] Z. Li, K. Jones, P. Zhang and R. Bowman, "Chromate Transport through Columns Packed with SurfactantModified Zeolite/Zero Valent Iron Pellets," Chemosphere, Vol. 68, No. 10, 2007, pp. 1861-1866. doi:10.1016/j.chemosphere.2007.03.011

[4] H. Faghihian and R. S. Bowman, "Adsorption of Chromate by Clinoptilolite Exchanged with Various Metal Cations," Water Research, Vol. 39, No. 6, 2005, pp. 10991104. doi:10.1016/j.watres.2004.12.010

[5] W. Simmons and D. Stewart, "Silica Mineral," Resource Document, Encyclopedia Britannica, 2006. http://www.britannica.com/EBchecked/topic/544154/silica

[6] C. E. Weaver and L. D. Pollard, "Developments in Sedimentology," Elsevier Scientific, Amsterdam, 1985.

[7] E. Besoain, "Soil Clay Mineralogy," Inter-American Institute for Cooperation on Agriculture, San José, 1985.

[8] D. Mohan and C. U. Pittman Jr., "Review Activated Carbons and Low Cost Adsorbents for Remediation of Triand Hexavalent Chromium from Water," Journal of Hazardous Materials, Vol. 137, No. 2, 2006, pp. 762-811. doi:10.1016/j.jhazmat.2006.06.060

[9] Y. C. Sharma, V. Srivastava, V. K. Singh, S. N. Kaul and
C. H. Weng, "Nano-Adsorbents for Removal of Metallic Pollutants from Water and Wastewater," Environmental Technology, Vol. 30, No. 6, 2009, pp. 583-609. doi:10.1080/09593330902838080

[10] K. Bhattacharyya and S. S. Gupta, "Adsorption of Chromium(VI) from Water by Clays," Industrial \& Engineering Chemistry Research, Vol. 45, No. 21, 2006, pp. 72327240. doi:10.1021/ie060586j

[11] P. K. Pandey, S. K. Sharma and S. S. Sambi, "Kinetics and Equilibrium Study of Chromium Adsorption on Zeolitenax," International Journal of Environmental Science and Technology, Vol. 7, No. 2, 2010, pp. 395-404.

[12] A. Gładysz, M. Majdan, S. Pikus and D. Sternik, "Simultaneous Adsorption of Chromium(VI) and Phenol on Natural Red Clay Modified by HDTM," Chemical Engineering Journal, Vol. 179, 2012, pp. 140-150. doi:10.1016/i.cej.2011.10.071

[13] W. Chih-Huang, Y. C. Sharma and S.-H. Chua, "Adsorption of $\mathrm{Cr}(\mathrm{VI})$ from Aqueous Solutions by Spent Activated Clay," Journal of Hazardous Materials, Vol. 155, No. 1-2, 2008, pp. 65-75. doi:10.1016/j.jhazmat.2007.11.029

[14] J. Dana, "Manual of Mineralogy," 2nd Edition, Reverte, 1973.

[15] P. K. Jal, S. Patel and B. K. Mishra, "Chemical Modification of Silica Surface by Immobilization of Functional Groups for Extractive Concentration of Metals Ion," Talanta, The International Journal of Pure and Applied Analytical Chemistry, Vol. 62, No. 5, 2004, pp. 10051028 .

[16] M. Gandhi and S. Meenakshi, "Preparation and Characterization of $\mathrm{La}$ (III) Encapsulated Silica Gel/Chitosan Composite and Its Metal Uptakes Studies," Journal of Hazardous Materials, Vol. 203-204, 2012, pp. 29-37. doi:10.1016/j.jhazmat.2011.11.062

[17] S. Douglas, "Recommended Nomenclature for Zeolite Mineral: Report of the Subcommittee on Zeolites of the International Mineralogical Association on New Minerals and Mineral Name," The Canadian Mineralogist, Vol. 35, 1997, pp. 1571-1606.

[18] V. Swarnakar, N. Agrawal and R. Tomar, "Sorption of $\mathrm{Cr}(\mathrm{VI}) \& \mathrm{As}(\mathrm{V})$ on HDTMA-Modified Zeolite," International Journal of Scientific \& Engineering Research, Vol. 2, No. 5, 2011, pp. 1-9.

[19] D. Breck, "Zeolite Molecular Sieves: Structure, Chemistry and Use," Wiley-Interscience Publication, New York, 1973.

[20] H. Tashauoei, H. Movahedian, M. Kamali, M. Amin and M. Nikaeen, "Removal of Hexavalent Chromium (VI) from Aqueous Solutions Using Surface Modified Nanozeolite A," International Journal of Environmental Research, Vol. 4, No. 3, 2010, pp. 491-500.

[21] M. Vaca, R. Loâ Pez, R. Gehr, B. Jimeânez and P. Álvarez, "Heavy Metal Removal with Mexican Clinoptilolite: Multi-Component Ionic Exchange," Water Research, Vol. 35, No. 2, 2001, pp. 373-378. doi:10.1016/S0043-1354(00)00270-0

[22] S. Kocaoba and Y. Orchan, "Heavy Metal Adsorption by 
Clinoptilolite from Aqueous Solutions," Faculty of Art and Science, Yylyl Technical University, 2003.

http://www.gisig.it/eco-imagine/abstract/Borsisti/Posters $\% 20 \mathrm{Genoa} /$ Kocaoba.PDF

[23] P. Rodríguez, I. Ávila, M. Rodríguez, B. Gener, M. Concepción, M. Rebollar, C. Betancourt, R. Covarrubias, R. Arriagada and R. García, "New Materials for Chromium (III) and (VI) from Industrial Waste," Iberoamerican Congress of Metallurgy and Materials, Habana, 2006.

[24] V. Swarnakar, N. Agrawal and R. Tomar, "Sorption of Chromate by HDTMA-Exchanged Zeolite," Journal of Chemical Pharmaceutical Research, Vol. 3, No. 3, 2011, pp. 520-529.

[25] R. Cortés. "Effect of Modification of Natural Mexican Zeolite Sorption of Cadmium and 4-Chlorophenol," Ph.D. Dissertation, Facultad de Ingeniería, Universidad Autónoma del Estado de México, 2007.
[26] V. Swarnakar, N. Agrawal and R. Tomar, "Sorption Chromate and Arsenate by Surfactant Modified Erionite," International Journal of Scientific \& Engineering Research, Vol. 33, No. 6, 2012, pp. 919-927.

[27] T. Bajda and Z. Klapyta, "Sorption of Chromate by Clinoptilolite Modified with Alkylammonium Surfactants," Journey of Polish Mineralogy, Vol. 37, No. 2, 2006, pp. 109-115.

[28] E. Chimielewska, "Adsorption of Arsenate and Chromate from Waters on Hydrophobized Zeolitic Media," Turkish Journal of Chemistry, Vol. 27, No. 5, 2003, pp. 639-648.

[29] C. Pérez, V. Granda, L. Pina and F. Torres, "Adsorption of $\mathrm{Cr}(\mathrm{VI})$ on a Surface Modified Clinoptilolite Mineral; Speciation of $\mathrm{Cr}(\mathrm{III})$ and $\mathrm{Cr}(\mathrm{VI})$ by FIA Coupled with Microcolumn," Cuban Journal of Chemistry, Vol. 15, No. 2, 2003, pp. 53-59. 